JMI Vol. 42 No. 1, Juni 2020

METAL INDONESIA



\title{
RECOVERY OF RARE EARTH ELEMENTS AND YITRIUM FROM NON-MAGNETIC COAL FLY ASH USING ACETIC ACID SOLUTION
}

\author{
Hotden Manurung ${ }^{1}$, Widya Rosita ${ }^{1}$, I Made Bendiyasa ${ }^{1}$, Agus Prasetya ${ }^{1}$, Ferian Anggara ${ }^{2}$, Widi \\ Astuti $^{3}$, Dagus Resmana Djuanda ${ }^{4}$, Himawan Tri Bayu Murti Petrus*1,5 \\ ${ }^{1}$ Departemen Teknik Kimia (Sustainable Mineral Processing Research Group), Fakultas \\ Teknik, Universitas Gadjah Mada, Jalan Grafika No. 2 Daerah Istimewa Yogyakarta \\ ${ }^{2}$ Departemen Teknik Geologi, Fakultas Teknik, Universitas Gadjah Mada, Jalan Grafika No. 2 \\ Daerah Istimewa Yogyakarta \\ ${ }^{3}$ Balai Penelitian Teknologi Mineral Lembaga Ilmu Pengetahuan Indonesia, Jalan Ir. Sutami, \\ Serdang, Kec Tanjung Bintang, Kabupaten Lampung Selatan, Lampung 35361 \\ ${ }^{4}$ Balai Besar Logam dan Mesin, Metal Industries Development Center - MIDC, Kementerian \\ Perindustrian, Jl. Sangkuriang No.12, Dago, Kecamatan Coblong, Kota Bandung, Jawa Barat 40135 \\ ${ }^{5}$ Unconventional Geo-resources Research Center, Faculty of Engineering, Universitas Gadjah \\ Mada, Jl. Grafika No. 2, Yogyakarta 55281, Indonesia \\ Email: *bayupetrus@ugm.ac.id
}

\begin{abstract}
The increasing need of REY has been observed in industries such as catalyst industry, metallurgy, military, health and renewable energy resources. REY such as $\mathrm{Ce}, \mathrm{Nd}, \mathrm{Y}$, and Eu has a prominent evidence to improve material properties such as high electropositive, good conductivity and renewable energy. Due to this increasing need of REY, exploration of alternative source has been conducted. One of the promising alternative sources is coal fly ash. The conventional method to recover REY from coal fly ash using inorganic acids is harmful to the environment. Thus, the exploration of REY extraction from coal fly ash using organic acid has been proposed in this study. The leaching agent was acetic acid applied for all operating condition. Regarding to the mineralization of REY in the form of siliceous minerals (nonmagnetic coal fly ash). Silicate digestion was conducted using sodium hydroxide $8 \mathrm{M}$ with solid-to-liquid of $25 \%$ to decompose the siliceous mineral. Further, the REY bound siliceous mineral will change to $\mathrm{REY}(\mathrm{OH})_{3}$. Temperature as one of the operating conditions was varied. The maximum recovery of leaching $20.58 \%, 43.53 \%, 17.38 \%, 40.96 \%, 18.45 \%$ and $32.74 \%$ were achieved for Ce, Dy, La, Nd, Y and Yb respectively at temperature of $90^{\circ} \mathrm{C} \mathrm{pH} 1.74$ and 120 minutes. For some metals, increasing the temperature higher than $70^{\circ} \mathrm{C}$ does not provide any significant effect for REY recovery such as La and Ce.
\end{abstract}

Keywords: REY, non-magnetic CFA, leaching, recovery

\section{INTRODUCTION}

Rare Earth Elements such as Ce, Dy, La, $\mathrm{Nd}, \mathrm{Yb}$ and Yittrium (Y) becomes important issue in the recent year. The increasing need of REY has been observed in industries such as catalyst industry, metallurgy, military, health and renewable energy resources (Zhou et al. 2017; Harjanto et al. 2013). Alonso et al (Alonso et al. 2012) reported that REY demand increase 5.3\% every years from 2010 until 2020. REY has a prominent evidence to improve material properties such as a high electropositive, good 
conductivity and renewable energy. Due to this increasing need of REY, exploration of alternative source has been conducted. There are some several alternative sources of REY such as red mud, spent catalyst, electronic waste, tin residue coal, coal fly ash and zircon sand (Abhilash et al., 2014; Aung and Ting, 2005; Borra et al., 2015; Sinha et al., 2014; Virdhian and Afrilindia Eva, 2014, Prameswara et al., 2020, Manurung et al., 2020). One of the promising alternative sources is coal fly ash and coal (Anggara et al., 2018; Anggara and Petrus, 2016; Peramaki, 2014). Anggara et al. (Ferian et al. 2018) recently reported that fly ash and bottom ash from Coal Power Plant in Java are promising raw material for REY extraction.

The existence of REY on coal fly ash were influenced by the coal rank and mineral matter or detrital mineral such as quarts, clay mineral, sulfide and phosphate (Finkelman et al 2018; Wang et al. 2008). Due to high temperature in combustion process, REY were melting and distributed into the fly ash component such ash quartz $\left(\mathrm{SiO}_{2}\right)$, mullite $\left(3 \mathrm{Al}_{2} \mathrm{O}_{3} \cdot 2 \mathrm{SiO}_{2}\right)$ and amorphous phase (Kashiwakura et al. 2013).

The mathematical formulation to estimate the prospect of REY from coal fly ash has a several parameters such as resources of metal, possibility of beneficiation, simplicity and hydrometallurgical recovery (Vladimir V Seredin and Dai 2012). The cut-off-grade for REY extraction should be minimum or $>1000 \mathrm{ppm}$. However, due to the increasing need of REY, the recent prices much higher than in the past. Moreover, at previous decade, this cut-off grade could be lowered to $800-900 \mathrm{ppm}$. The present criterion to evaluate the REY in the coal fly ash based on the individual composition of the metal (elements). It was divided in three classification such as critical (Nd, Eu, Tb, Dy, Y and Er), uncritical (La, Pr, Sm and $\mathrm{Gd})$ and excessive (Ce, Ho, Tm, Yb and Lu) (V V Seredin 2010). Critical is an element with very low amount and high demand, uncritical is a medium and excessive is the most abundant element occurrences. For preliminary estimation of raw material quality, there was a ratio of relative amount of critical REY in total REY to the relative amount of excessive REY. The index called outlook coefficient of REY. The equations used to calculate the outlook is as follow (equation 1):
$\mathrm{C}_{\text {out }}=\frac{(\mathrm{Nd}+\mathrm{Eu}+\mathrm{Tb}+\mathrm{Dy}+\mathrm{Er}+\mathrm{Y}) /\left(\sum \mathrm{REY}\right)}{(\mathrm{Ce}+\mathrm{Hp}+\mathrm{Tm}+\mathrm{Yb}+\mathrm{Lu}) /\left(\sum \mathrm{REY}\right)} \ldots \ldots . . .(1)$

The minimum $\mathrm{C}_{\text {out }}$ index is 0.7 . The higher $\mathrm{C}_{\text {out }}$ the more promising REY raw material to extract $(\mathrm{V} \mathrm{V}$ Seredin 2010).

Hydrometallurgy is the most efficient method for extract some metal for low concentration, because it consumes little energy, emits small amounts of gases and high recovery. Leaching is one of hydrometallurgy process, where acid used as the leaching agent to extract element from the coal fly ash. Conventionally, inorganic acids used as the leaching agents such as $\mathrm{H}_{2} \mathrm{SO}_{4}, \mathrm{HCl}$, and $\mathrm{HNO}_{3}$ (Kashiwakura et al. 2013; Peramaki 2014). Anyway, in-organic acid in the leaching process produces harmful byproduct. In the recent years, researchers have investigated the use of organic acid to substitute the in-organic acid as a leaching agent such as citric acid, acetic acid, oxalic acid and nitric acid (Wanta et al. 2016; Wanta et al. 2018; Lazo et al. 2017; Setiawan et al. 2019; Sekar et al. 2018; Sari et al. 2018). The use of organic acid often called as an environmentally friendly leaching agent.

This study aims to investigate the use of acetic acid as an environmentally friendly leaching agent. Acetic acid has been demonstrated to leach neodymium from the scrub magnetic leaching (Behera and Parhi 2016). Moreover acetic acid also has been demonstrated to leach $\mathrm{Li}$ and Co from spent lithium-ion batteries (Setiawan et al. 2019). Regarding to the mineralization of REY in the form of siliceous minerals (nonmagnetic coal fly ash). Silicate digestion was conducted using sodium hydroxide to decompose the siliceous mineral and enable the leaching of REY. Further the REY bound siliceous mineral will change to $\mathrm{REY}(\mathrm{OH})_{3}$.

\section{RESEARCH METODOLOGY Material}

Coal fly ash (CFA) were collected from Coal Fired Power Plan (PLTU) Tuban East Java. Particle size less than $38 \mu \mathrm{m}$ (- 400 mesh) were used as a raw material. Non-magnetic component and magnetic component were separate using wet magnetic separator with 2 A current at Mineral and Coal Technology Reaseach and Development (PUSLITBANG TekMIRA) Bandung west Java. 
XRD analysis were aplied to identify the material characterization using XRD X'Pert 3 Powder instrument. The Non-magnetic component analysis using ICP-MS both major elements and REY in ALS Global - Geochemistry Analytical Lab in North Vancouver, BC, Canada.

\section{Silicate Digestion}

The digestion was done using sodium hydroxide $\mathrm{NaOH}$ pro-analysis produced by Merck Inc. The digestion process was conducted in a three-necked flask by mixing 62,5 g non-magnetic component of CFA with $250 \mathrm{~mL}$ (solid-to-liquid $25 \% \mathrm{w} / \mathrm{v})$ of sodium hydroxide $8 \mathrm{M}(\mathrm{pH} \mathrm{13,9).}$ The reagent was heated using waterbath eqipped with reflux condenser and stirrer operated at a speed $500 \mathrm{rpm}$ than heated to $90^{\circ} \mathrm{C}$ at atmospheric condition. They were digested for 120 minute to breakage the silicate content. The digested residue were washed using destilated water (60x) using dry sample wight based and dried at temperature $100^{\circ} \mathrm{C}$ during 5 hours using oven. This solid were used as a material for acid leaching.

\section{Metal Leaching}

Acetic acid (100vol\%) pro-analysis was used as a leaching reagent, produced by Merck Inc. The leaching process was conducted in a three-necked flask by mixing $25 \mathrm{~g}$ sample with $250 \mathrm{~mL}$ (solid to liquid $10 \% \mathrm{w} / \mathrm{v}$ ) of acetic acid $50 \%$ ( $\mathrm{pH}$ 1.72). The reagent was heated using a mantle heater equipped with reflux condenser and with a stirred operated at speed $500 \mathrm{rpm}$ than heated at $30^{\circ} \mathrm{C}$ (room temperature), $70^{\circ} \mathrm{C}$ and $90^{\circ} \mathrm{C}$. Temperature as one of the operating condition was varied. They were leached for 120 minutes to dilute the REY from non-magnetic CFA. The peocess flow-sheet was presented in Figure 1 from raw material until leaching step.

\section{ICP-EAS Analysis and XRD Analysis}

Sample preparation was carried out by diluting $2 \mathrm{~mL}$ of leached to $10 \mathrm{~mL}$ ( $5 \mathrm{x}$ dilution) using aqua for injection. The samples was filtered using a $0.22 \mu \mathrm{m}$ micro filter to separate any suspended solid in the filtrate. The filtrate was analyzed using ICP-AES (Simadzu Europe) in LPPT UGM to find the amount REY recovered by leaching. Sample preparation for XRD analysis was carried out by weighing dry samples $10 \mathrm{gr}$ for raw material (non-magnetic coal fly ash), after silicate digestion and after acid leaching using XRD X'Pert 3 Powder instrument.

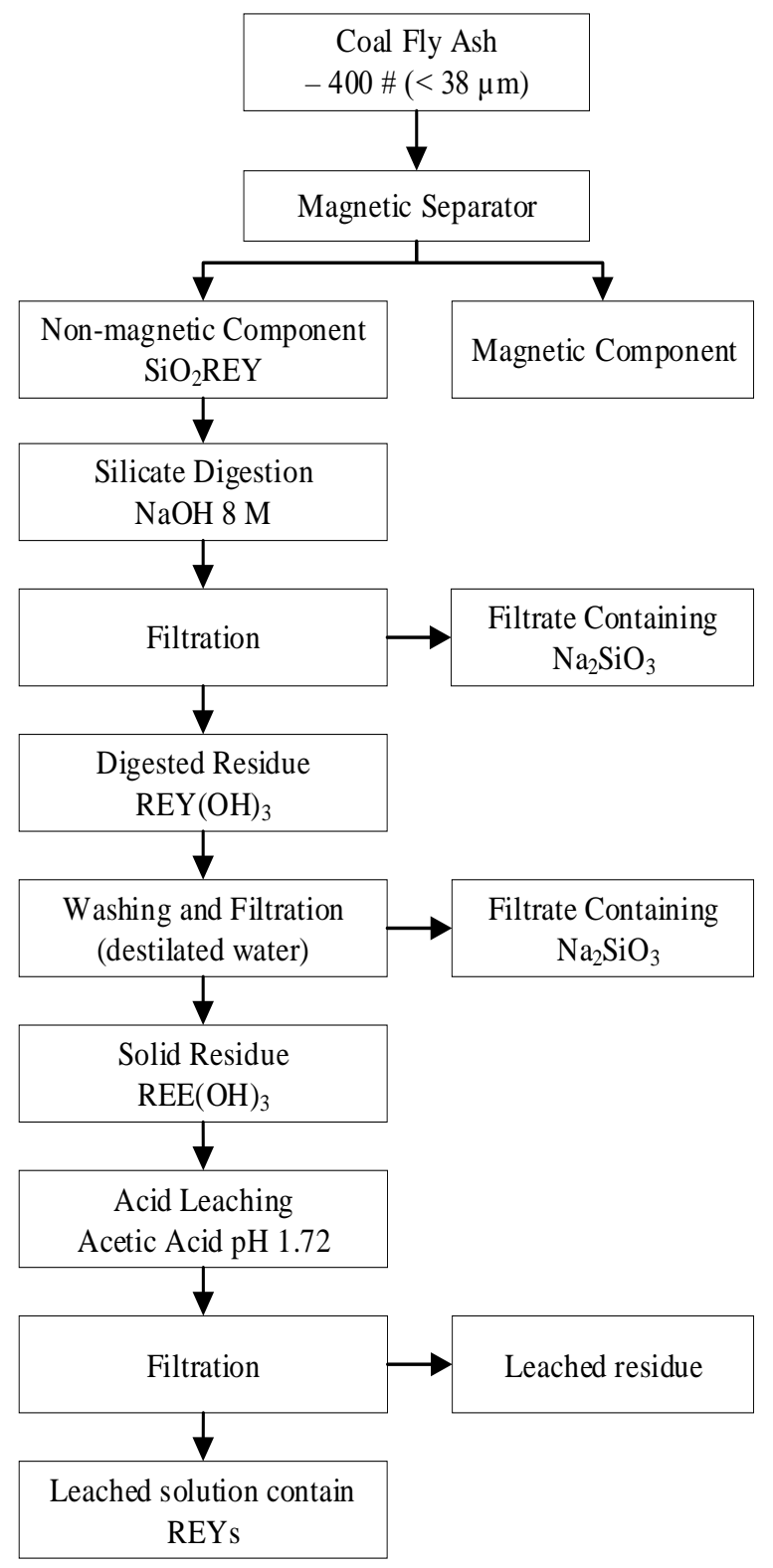

Figure 1. Process flow-sheet for extracting REE from coal fly ash

\section{RESULT AND DISCUSSION Raw Material Characterization}

Raw material characterization was conducted using XRD analysis and ICP-MS instrument for major composition and rare earth concentration. Based on the major element analysis shows that non-magnetic coal fly ash contain $\mathrm{SiO}_{2}, \mathrm{Al}_{2} \mathrm{O}_{3}, \mathrm{Fe}_{2} \mathrm{O}_{3}, \mathrm{CaO}$ and $\mathrm{MgO}$ as a 
major mineral and $\mathrm{K}_{2} \mathrm{O}, \mathrm{Cr}_{2} \mathrm{O}_{3}, \mathrm{TiO}_{2}, \mathrm{MnO}, \mathrm{P}_{2} \mathrm{O}_{5}$, $\mathrm{SrO}$ and $\mathrm{BaO}$ as a minor mineral (Table 1). $\mathrm{SiO} 2$ is the most abundance major element for nonmagnetic coal fly ash. The rare earth lements concentration were presented in Table 2. Cerium is the higher concentration for exessive and Yittrium fro crtical. Based on the XRD analysis shows that quarts, mulite, hematite and khamosite (Figure 3 sample A). Rare earth elements were not appear in this analysis due to very small amout (ppm) and rare earth element were not mineralized but only distributed and sticky on the silicate and glass phase after combustion process (Kashiwakura et al. 2013; Peramaki 2014).

Table 1. Major element in nonmagnetic component of CFA

\begin{tabular}{cccc}
\hline $\begin{array}{c}\text { Major } \\
\text { Element }\end{array}$ & $\mathrm{Wt}(\%)$ & $\begin{array}{c}\text { Major } \\
\text { Element }\end{array}$ & $\mathrm{Wt}(\%)$ \\
\hline $\mathrm{SiO}_{2}$ & 53.20 & $\mathrm{Cr}_{2} \mathrm{O}_{3}$ & 0.01 \\
$\mathrm{Al}_{2} \mathrm{O}_{3}$ & 31.90 & $\mathrm{TiO}_{2}$ & 1.15 \\
$\mathrm{Fe}_{2} \mathrm{O}_{3}$ & 5.58 & $\mathrm{MnO}$ & 0.06 \\
$\mathrm{CaO}$ & 3.08 & $\mathrm{P}_{2} \mathrm{O}_{5}$ & 0.24 \\
$\mathrm{MgO}$ & 2.11 & $\mathrm{SrO}$ & 0.08 \\
$\mathrm{Na}_{2} \mathrm{O}$ & 0.90 & $\mathrm{BaO}$ & 0.07 \\
$\mathrm{~K}_{2} \mathrm{O}$ & 0.99 & LOI & 1.09 \\
\hline
\end{tabular}

Table 2. REY concentration in non-magnetic coal fly ash

\begin{tabular}{ll}
\hline REY Elements & Unit $(\mathrm{ppm})$ \\
\hline $\mathrm{Ce}$ & 98.3 \\
$\mathrm{Dy}$ & 9.32 \\
$\mathrm{La}$ & 49 \\
$\mathrm{Nd}$ & 45.2 \\
$\mathrm{Y}$ & 53.2 \\
$\mathrm{Yb}$ & 6.08 \\
\hline
\end{tabular}

Based on the Table 2 (another elements concentration not shown), the Cout can be calculated using equation (1):

$$
\begin{aligned}
& \text { Cout }=\frac{(\mathrm{Nd}+\mathrm{Eu}+\mathrm{Tb}+\mathrm{Dy}+\mathrm{Er}+\mathrm{Y}) /\left(\mathrm{ERES}^{\mathrm{N}}\right)}{\left.\left(\mathrm{C}_{\theta}+\mathrm{Hp}+\mathrm{Tm}+\mathrm{Yb}+\mathrm{Lu}\right) / \mathrm{EREY}^{\mathrm{R}}\right)} \\
& \text { Cout }=1.068 . \\
& \text { Cout }=1.068(\text { Cout }>0.7) \text { indicate that }
\end{aligned}
$$
REY in non magnetic coal fly ash are promising to extract.

\section{Studies for Silicate Digestion and recovery}

The presence of silicate component in non-magnetic coal fly ash decrease the REY recovery. Dissolving silicate component become an essential point to remove. Silicate digestion can be achived by alkaline fusion or alkaline leaching. $\mathrm{NaOH}$ solvent was used to as a leachant to breakage and solubilize the silicious component(Manurung et al., 2020). During the silicate digestion of coal fly ash, its constituent's at elevated temperatures takes place according to the reaction (Ian McGill 2012).

$2 \mathrm{SiO}_{2} \mathrm{REY}_{(s)}+4 \mathrm{NaOH}_{(a q)}+4 \mathrm{H}_{2} \mathrm{O}_{(\mathrm{aq})} \rightarrow$

$2 \mathrm{Na}_{2} \mathrm{SiO}_{3(a q)}+2 \mathrm{REY}(\mathrm{OH})_{3(s)}+3 \mathrm{H}_{2(g)}$

Where $\mathrm{SiO}_{2} \mathrm{REY}$ was transformed to natriumsilicate salt and REY change the bound as a $\operatorname{REY}(\mathrm{OH})_{3}$. The filtrate were analyzed to identify the amount of silicate and REY in the liquor. Based on the analysis data shows that $\mathrm{SiO}_{2}$ were dilute $20 \%$ until $40 \%$ during silicate digestion.

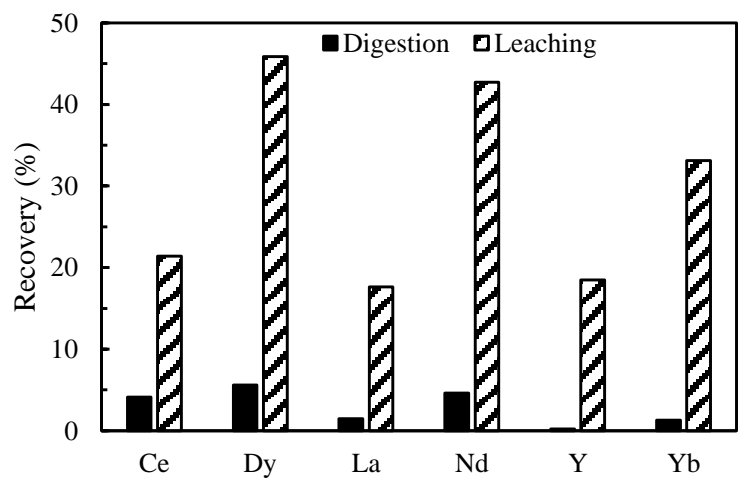

Figure 2. Recovery of REY after digestion process and leaching at temperature $90^{\circ} \mathrm{C}$

The recovery of REY during silicate digestion were presented in Figure 2. The REY recovery during silicate digestion $5.5 \%, 4.6 \%$ and $4.1 \%$ were achieved for $\mathrm{Dy}, \mathrm{Nd}$ and $\mathrm{Ce}$ respectively. It shows that only small amount of REY were diluted during silicate digestion compare to acid leacing at the same temperature $\left(90^{\circ} \mathrm{C}\right)$. Furthermore, when silicate component were decomposed, rare earth elements were transformed to rare earth oxide $\left(\mathrm{REY}(\mathrm{OH})_{3}\right)(\mathrm{Ian}$ McGill 2012). Gupta at al. (Nagaiyar dan Gupta 2016) also reported that alkaline fusion using $\mathrm{NaOH}$ solid was applied to recovery rare earth element from monazite $\left(\mathrm{CePO}_{4}\right)$ to removed posphate as a pretreatment to form cerium-oxide before acid leaching. Beside that, alkaline fusion 
or roasting using $\mathrm{NaOH}$ were applied to recovery rare earth element from xenotime and bastnasite to convert rare eart elements to rare earth oxide(Rekha et al. 2014; Huang et al. 2017).

The XRD analysis shows that there were no significant peack diffrents for raw material and after silicate digiestion for quarts and mullite (Figure. 3; sample A and sample B). It shows that silicate digestion were dissolve the amorphous phase and glass mineral such as quarts and mullite(Kashiwakura et al. 2013).

\section{Acid Leaching of REY from Non-magnetic Coal Fly Ash}

The non-magnetic coal fly ash was leached using acetic acid. Acid leaching were cunducted at $\mathrm{pH} 1.72$ at various temperature $\left(30^{\circ} \mathrm{C}, 70^{\circ} \mathrm{C}\right.$ and $\left.90^{\circ} \mathrm{C}\right)$ in 120 minute. The acid leaching using acetic acid were used to leach the REY from REY.(OH $)_{3}$. The general reaction for acid leaching using acetic acid can be describe as equation (3)(Krishnamurthy dan Gupta 2016).



Where REY. $(\mathrm{OH})_{3}$ is transformed to REY. $\left(\mathrm{CH}_{3} \mathrm{COO}\right)_{3}$ in a liquid phase. Ion $\mathrm{H}^{+}$from acetic acid was successfully to replace the REY bound and dissolve the REY. In order to assure the chemical reaction, XRD analysis were conducted (Figure 3; sample C, D and D). It shows that, there were no significant peack diffrent for each mineral and REY not visible due to very low concentration.

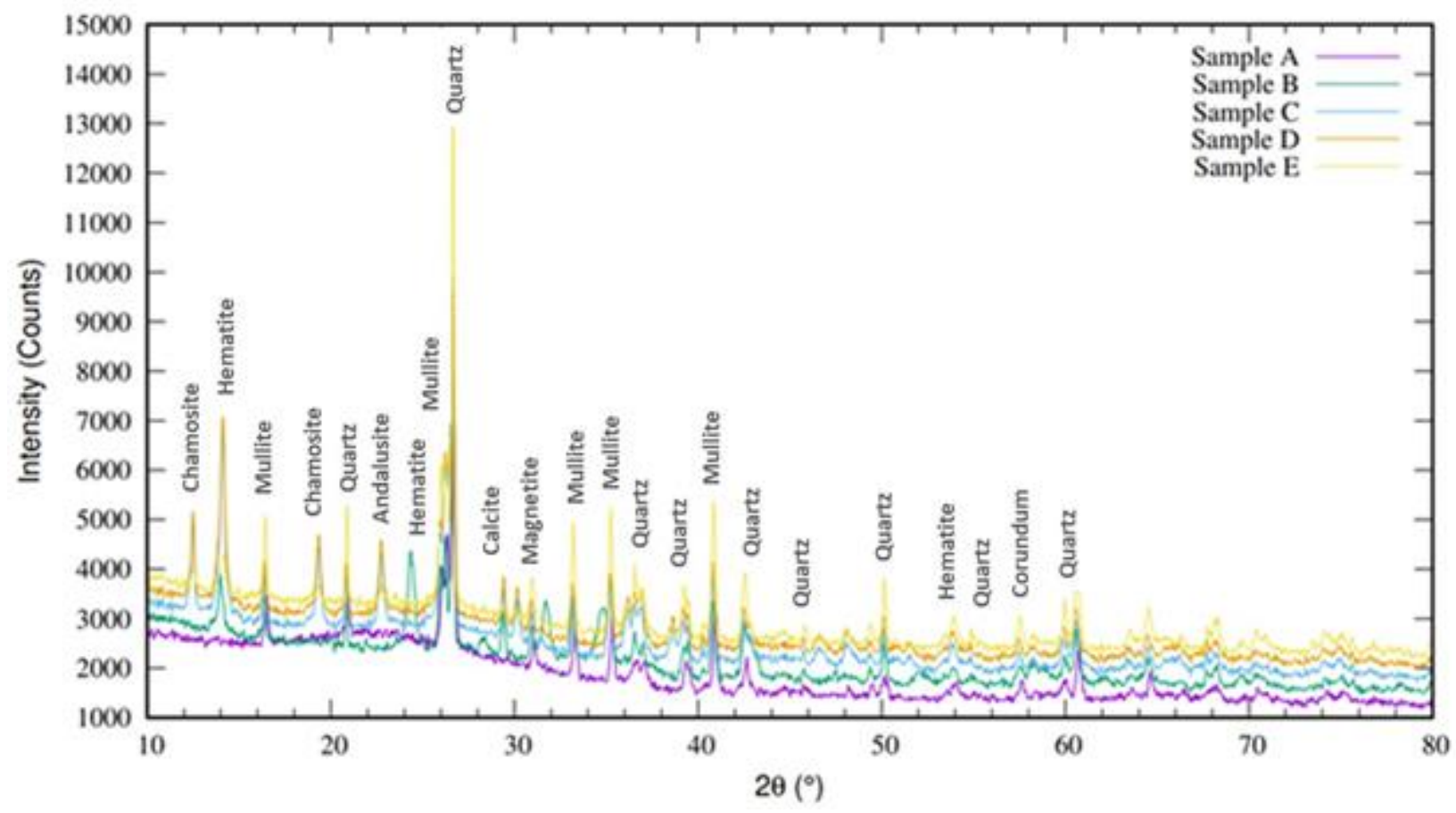

Figure 3. XRD analysis Pattern for coal flly ash (Sample A: raw material, Sampel B: after silicate digestoin, Sample C: acid leaching at temperature $90^{\circ} \mathrm{C}$, Sample D: acid leaching at temperature $60^{\circ} \mathrm{C}$ and Sample E: acid leaching at temperature $30^{\circ} \mathrm{C}$ )

The recovery of REY metal such as Ce, $\mathrm{Dy}, \mathrm{La}, \mathrm{Nd}, \mathrm{Y}$ and $\mathrm{Yb}$ were calculated in certain temperature. Based on the Arrhennius rule shows that, temperature is a one of the main parameter on chemical process due to process rate. The effect of temperature on REY recovery shown in Figure. 
4. It shows that temperature influence the REY recovery. Increasing temperature, the rate of REY recovery also increased(Manurung et al., 2020). This phenomenon is consistent with the Arrhenius rate law, which states that an increase the temperature will increase the rate of reaction, increase in temperature of 10 degrees can increase the reaction rate twice(Fogler 2005).

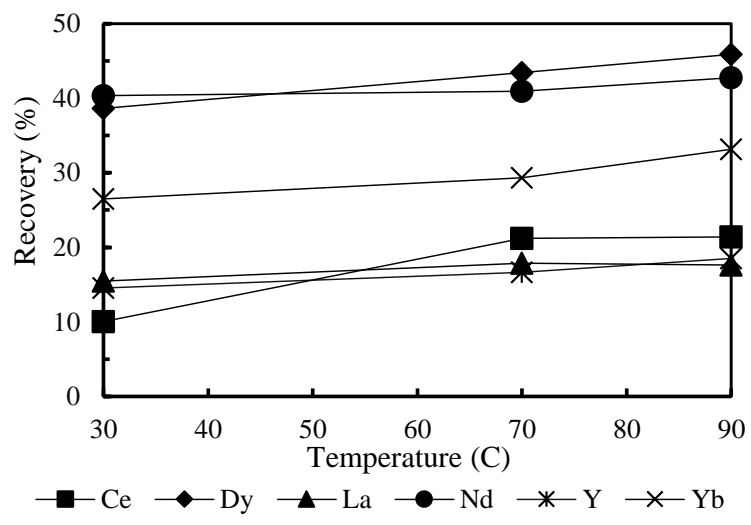

Figure 4. Recovery of REY at various temperature ( $\mathrm{pH}$ 1.72, $500 \mathrm{rpm}, \mathrm{S} / \mathrm{L} 10 \%, 120$ $\min )$

The temperature need to achieve the maximum recovery of each REY element were diffrent. For Cerium (Ce), the recovery were excessively increase at temperature $30^{\circ} \mathrm{C}$ to $70^{\circ} \mathrm{C}$, the resulting recovery increase from $9.68 \%$ to $20.41 \%$ (increase 10.72\%). Increasing temperature until $90^{\circ} \mathrm{C}$ was slightly increse the Ce recovery, it was from $20.41 \%$ to $20.58 \%$. Lyberopulu and Ochsenkiihn (Lyberopulu dan Ochsenkiihn 1996) reported that leaching cerium from red mud achived the optimum conditons at $80^{\circ} \mathrm{C}$ using $\mathrm{HNO} 3, \mathrm{HCL}$ and $\mathrm{H} 2 \mathrm{SO} 4$, the recovery were $29 \%, 32 \%$ and $24 \%$ respectively. There were $10 \%$ recovery diffrent between organic and inorganic acid

Dysprosium (Dy) element shows that, increasing the temperature from $30^{\circ} \mathrm{C}$ to $70^{\circ} \mathrm{C}$ and $90^{\circ} \mathrm{C}$ were increase the Dy recovery, it was $36.69 \%, 41.24 \%$ and $43.53 \%$. The Dy recovery was increse step by step due to increse the temperature. For Lantanum (La) element shows that increasing temperature from $30^{\circ} \mathrm{C}$ to $70^{\circ} \mathrm{C}$ were increase the recovery from $15.29 \%$ to $17.62 \%$. However at temperature $90^{\circ} \mathrm{C}$ the $\mathrm{La}$ recovery decrese from $17.62 \%$ to $17.38 \%$. For
Neodymium ( $\mathrm{Nd}$ ) element shows that, increasing temperature from $30^{\circ} \mathrm{C}$ to $70^{\circ} \mathrm{C}$ were increase the recovery from $38.67 \%$ to $39.22 \%$. Increasing temperature until $90^{\circ} \mathrm{C}$ was increse the recovery from $39.22 \%$ to $40.96 \%$. There were no significant effect of temperature to $\mathrm{Nd}$ recovery. Migdisov and William(Migdisov dan Williams-Jones 2007) reported that neodymium solubility increase above $150^{\circ} \mathrm{C}$ in F-bearing aqueous solutions, due to high stability of neodymium.

Yittrium (Y) element shows that, increasing temperatue from $30^{\circ} \mathrm{C}$ to $70^{\circ} \mathrm{C}$ and $90^{\circ} \mathrm{C}$ were increase the recovery of yittrium from $14.51 \%, 16.63 \%$, and $18.45 \%$ respectively. For $\mathrm{Yb}$ element shows that temperature influence the $\mathrm{Yb}$ recovery from temperature $30^{\circ} \mathrm{C}, 70^{\circ} \mathrm{C}$ and $90^{\circ} \mathrm{C}$ were increase from $26.18 \%, 28.98 \%$ and $32.74 \%$.

\section{CONCLUSION}

Based on the experiments and discussion conclude that temperature $\left(30^{\circ} \mathrm{C}, 70^{\circ} \mathrm{C}\right.$ and $\left.90^{\circ} \mathrm{C}\right)$ influence the REY recovery. Overall the hinger temperature the hinger REY recovery. The maximum recovery $20.58 \%, 43,53 \%, 17.38 \%, 40.96 \%, 18.45 \%$ and $32.74 \%$ were achieved for Ce, Dy, La, Nd, Y and $\mathrm{Yb}$ respectively at temperature $90^{\circ} \mathrm{C}$ and 120 minutes. Otherwise for some metal, the increasing temperature more than $70^{\circ} \mathrm{C}$ does not have a significant effect for REY metal recovery such as $\mathrm{La}$ and $\mathrm{Ce}$.

\section{ACKNOWLEDGEMENT}

This research was financially supported by Kementerian Riset, Teknologi, dan Pendidikan Tinggi Republik Indonesia on Pendanaan Tesis Magister Program tahun 2019 with contract number 2869/UN1.DITLIT/DIT-LIT/LT/2019. The authors would like to thank Dr. I Wayan Warmanda for his support in this research.

\section{REFERENCES}

Abhilash, Shivendra Sinha, Kumar Sinha Manish, dan Dhar Pandey Banshi. 2014. "Extraction of lanthanum and cerium from Indian red mud." International Journal of Mineral Processing 127: 70-73.

Alonso, Elisa, Andrew M Sherman, Timothy J Wallington, Mark P Everson, Frank R Field, Richard Roth, dan Randolph E Kirchain. 2012. "Evaluating Rare Earth Element 
Availability: A Case with Revolutionary Demand from Clean Technologies."

Anggara, Ferian, D. Hendra Amijaya, Agung Harijoko, Theodora Noely Tambaria, Amanda Ayudia Sahri, dan Zain Andrian Nur Asa. 2018. "Rare earth element and yttrium content of coal in the Banko coalfield, South Sumatra Basin, Indonesia: Contributions from tonstein layers." International Journal of Coal Geology 196 (July): 159-72. https://doi.org/10.1016/j.coal.2018.07.006.

Aung, Khin Moh Moh, dan Yen Peng Ting. 2005. "Bioleaching of spent fluid catalytic cracking catalyst using Aspergillus niger." Journal of Biotechnology 116 (2): 159-70. https://doi.org/10.1016/j.jbiotec.2004.10.00 8.

Behera, S S, dan P K Parhi. 2016. "Leaching kinetics study of neodymium from the scrap magnet using acetic acid." Separation and Purification Technology 160: 59-66. https://doi.org/10.1016/j.seppur.2016.01.01 4.

Borra, Chenna Rao, Yiannis Pontikes, Koen Binnemans, dan Tom Van Gerven. 2015. "Leaching of rare earths from bauxite residue ( red mud )." Minerals Engineering 76:

$20-27$.

https://doi.org/10.1016/j.mineng.2015.01.00 5.

Ferian, Anggara, Bestari Dea Anisa Ayu, Rosita Widya, dan Petrus Himawan Bayu Tri Murti. 2018. "The Composition and mode of occurence of rare earth elements and yittrium in fly ash and bottom ash from coalfired plants in Java, Indoneisa." The Society for Oorganic Petrology Annual Meeting.

Ferian, Anggara, dan M Petrus Himawan T. 2016. "Potential Source of Rare Earth elements (REE) from Sangatta Coal, Kuta Basin, Indonesia." Annual Meeting of The Society for Organic Petroligy 32 (170): 9-10. https://doi.org/10.1016/0166.

Finkelman, Robert B, Curtis A Palmer, dan Peipei Wang. 2018. "International Journal of Coal Geology Quantification of the modes of occurrence of 42 elements in coal." International Journal of Coal Geology 185 (September 2017): 138-60. https://doi.org/10.1016/j.coal.2017.09.005.
Fogler, H. Scott. 2005. Elements of Chemical Reaction Engineering. Diedit oleh Acrivos Andreas, Dahler John, HAnratty J Thomas, dan Sciven L E. Fourth Edi. Michigan United States America: Prentice Hall Proffessional TEchnical Reference.

Huang, Yukun, Zhihe Dou, Ting-an Zhang, dan Jiang Liu. 2017. "Hydrometallurgy Leaching kinetics of rare earth elements and fl uoride from mixed rare earth concentrate after roasting with calcium hydroxide and sodium hydroxide." Hydrometallurgy 173 (July): $15-21$. https://doi.org/10.1016/j.hydromet.2017.07. 004.

Ian McGill. 2012. "Rare Earth Elements." Ullmann's Encyclopedia of Industrial Chemistry Vol. 31. https://doi.org/10.1002/14356007.a22.

Kashiwakura, Shunsuke, Yuichi Kumagai, Hiroshi Kubo, dan Kazuaki Wagatsuma. 2013. "Dissolution of Rare Earth Elements from Coal Fly Ash Particles in a Dilute H2SO4 Solvent” 2013 (May): 69-75.

Krishnamurthy, Nagaiyar, dan Chairanjib Kumar Gupta. 2016. Extractive Metallurgy of Rare Earths. Diedit oleh Krishnarpanam Sri. Second Edi. United States of America: Taylor \& Francis Group, LLC.

Lazo, Daniel E, Laurence G Dyer, Richard Diaz Alorro, dan Richard Browner. 2017. "Hydrometallurgy Treatment of monazite by organic acids I : Solution conversion of rare earths." Hydrometallurgy 174 (October): 202-9.

https://doi.org/10.1016/j.hydromet.2017.10. 003.

Lyberopulu, Th, dan K M Ochsenkiihn. 1996. "Recovery of lanthanides and yttrium from red mud by selective leaching" 319: 249-54.

Migdisov, Art A., dan A. E. Williams-Jones. 2007. "An experimental study of the solubility and speciation of neodymium (III) fluoride in Fbearing aqueous solutions $>$." Geochimica et Cosmochimica Acta 71 (12): 3056-69. https://doi.org/10.1016/j.gca.2007.04.004.

Nagaiyar, Krishnamurthy, dan Chiranjib Kumar Gupta. 2016. Extractive Metallurgy of Rare Earth. Second Edi. CRC Press Taylor \& Francis Group Boca Raton London New York. 
Peramaki, Siiri. 2014. "Method Development for Determination and Recovery of Rare Earth Elements from Industrial Fly Ash.”

Rekha, Panda, Kumari Archana, Kumar Jha Manis, Hait Jhumki, Kumar Vinay, Rajesh J. Kumar, dan Lee Jin Young. 2014. "Leaching of rare earth metals (REMs) from Korean monazite concentrate.pdf." Journal of Industrial and Engineering Chemistry 20 (2014). https://doi.org/http://dx.doi.org/10.1016/j.jic .2013.09.028.

Sari, Dewi Purnama, Ahmad Tawfiequrahman, Himawan Tri, Bayu Murti, Fika Rofiek Mufakir, Widi Astuti, Y Iskandar, dan D Bratakusuma. 2018. "Valuable Metals Extraction From Hydrocracking Spent Catalyst Using Citric Acid." Seminar Nasional Teknik Kimia "Kejuangan": Pengembangan Teknologi Kimia untuk Pengolahan Sumber Daya Alam Indonesia, no. April: 1-5.

Sekar, Himmah, Eka Ayu, I Made Bendiyasa, Himawan Tri, Bayu Murti, Fika Rofiek, dan Widi Astuti. 2018. "Pelindian Nikel dari Bijih Limonit Low-Grade Pomalaa Menggunakan Pelarut Asam Asetat," no. April: 1-7.

Seredin, V V. 2010. "SHORT COMMUNICATIONS A New Method for Primary Evaluation of the Outlook for Rare Earth Element Ores" 52 (5): 475-80. https://doi.org/10.1134/S107570151005007 7.

Seredin, Vladimir V, dan Shifeng Dai. 2012. "International Journal of Coal Geology Coal deposits as potential alternative sources for lanthanides and yttrium." International Journal of Coal Geology 94: 67-93. https://doi.org/10.1016/j.coal.2011.11.001.

Setiawan, Hendrik, Himawan Tri Bayu Murti Petrus, dan Indra Perdana. 2019. "Reaction kinetics modeling for lithium and cobalt recovery from spent lithium-ion batteries using acetic acid." International Journal of Minerals, Metallurgy and Materials 26 (1): 98-107. https://doi.org/10.1007/s12613019-1713-0.

Sinha, Shivendra, Manish Kumar, dan Banshi Dhar. 2014. "International Journal of Mineral Processing Extraction of lanthanum and cerium from Indian red mud." International Journal of Mineral Processing 127: 70-73. https://doi.org/10.1016/j.minpro.2013.12.00 9.

Virdhian, Shinta, dan Afrilindia Eva. 2014. "Karakterisasi Mineral Tanah Jarang Ikutan Timah dan Potensi Pengembangan Industri Berbasis Unsur Tanah Jarang." Jurnal Metal Indoensia 36 (2): 61-69.

Wang, Wenfeng, Yong Qin, Shuxun Sang, Yanming Zhu, Chaoyong Wang, dan Dominik J Weiss. 2008. "International Journal of Coal Geology Geochemistry of rare earth elements in a marine in $\mathrm{fl}$ uenced coal and its organic solvent extracts from the Antaibao mining district, Shanxi , China." International Journal of Coal Geology 76 (4): 309-17. https://doi.org/10.1016/j.coal.2008.08.012.

Wanta, K. C., I. Perdana, dan H. T.B.M. Petrus. 2016. "Evaluation of shrinking core model in leaching process of Pomalaa nickel laterite using citric acid as leachant at atmospheric conditions." IOP Conference Series: Materials Science and Engineering 162 (1). https://doi.org/10.1088/1757899X/162/1/012018.

Wanta, Kevin Cleary, Felisha Hapsari Tanujaya, Ratna Frida Susanti, Himawan Tri Bayu Murti Petrus, Indra Perdana, dan Widi Astuti. 2018. "Studi Kinetika Proses Atmospheric Pressure Acid Leaching Bijih Laterit Limonit Menggunakan Larutan Asam Nitrat Konsentrasi Rendah." Jurnal Rekayasa Proses $12 \quad$ (2): 19. https://doi.org/10.22146/jrekpros.35644.

Zhou, Baolu, Zhongxue Li, dan Congcong Chen. 2017. "Global Potential of Rare Earth Resources and Rare." https://doi.org/10.3390/min7110203. 